\title{
Natural hazards in Australia: sea level and coastal
}

\section{extremes}

3

4 Kathleen L. McInnes, kathleen.mcinnes@csiro.au

5

6 Christopher J.White, chris.white@utas.edu.au

7 Ivan D. Haigh, I.D.Haigh@soton.ac.uk

8 Mark A. Hemer, mark.hemer@csiro.au

9 Ron K. Hoeke, ron.hoeke@csiro.au

10 Neil J. Holbrook, Neil.Holbrook@utas.edu.au

11 Anthony S. Kiem, Anthony.Kiem@newcastle.edu.au

12 Eric C. J. Oliver, Eric.Oliver@utas.edu.au

13 Roshanka Ranasinghe, R.Ranasinghe@unesco-ihe.org

14 Kevin J. E. Walsh, kevin.walsh@unimelb.edu.au

15 Seth Westra, seth.westra@adelaide.edu.au

16 Ron Cox, r.cox@wrl.unsw.edu.au 


\section{Abstract}

23 The Australian coastal zone encompasses tropical, sub- and extra-tropical climates and 24 accommodates about $80 \%$ of Australia's population. Sea level extremes and their physical 25 impacts in the coastal zone arise from a complex set of atmospheric, oceanic and terrestrial 26 processes that interact on a range of spatial and temporal scales and will be modified by a 27 changing climate, including sea level rise. This review details significant progress over recent 28 years in understanding the causes of past and projections of future changes in sea level and 29 coastal extremes, yet a number of research questions, knowledge gaps and challenges

30 remain. These include efforts to improve knowledge on past sea level extremes, integrate a

31 wider range of processes in projections of future changes to sea level extremes, and focus

32 efforts on understanding long-term coastline response from the combination of contributing 33 factors. 


\section{Introduction}

37 Australia's coastal zone - defined herein as the region of low-elevation coastal land and adjacent estuarine and marine ecosystems - is bisected by approximately $34,000 \mathrm{~km}$ of coastline and encompasses tropical, sub- and extra-tropical climates. The arid nature of much of Australia's interior means that approximately $80 \%$ of Australia's population lives in or near the coastal zone together with a diversity of coastal and estuarine ecosystems, making it of critical importance for a range of social, economic and environmental reasons.

In this review paper, our region of relevance extends from the continental shelf offshore, where oceanic processes responsible for extreme sea levels occur, through to the low-lying coastal land inshore where physical impacts are felt. Sea level extremes and their coastal impacts arise from a complex set of atmospheric, oceanic and terrestrial processes that interact on a range of spatial and temporal scales. These extremes may be characterized by their frequency, intensity, spatial extent, duration, and timing - all of which can be modified by a changing climate (Seneviratne et al. 2012). Understanding the factors that cause extremes and their trends under present climate conditions is fundamental to determining future impacts. Furthermore, understanding the response of systems (physical, ecological and socioeconomic) to extreme events and projecting their future changes is essential to managing and adapting to those extremes in the face of a changing climate (Leonard et al. 2014).

This review focuses on sea level and coastal extremes, forming part of this Special Issue describing changes in natural hazards in Australia (Westra et al. this issue). After summarizing our current scientific understanding of sea level and coastal extremes, this review concludes 
by highlighting key knowledge gaps and providing recommendations of future research priorities. Related hazards are discussed in the companion reviews.

\section{Understanding sea level and coastal extremes in Australia}

\subsection{Causes of sea level and coastal extremes}

Sea level and coastal extremes can arise from singular oceanic phenomena such as storm surges but more commonly arise from a combination of natural phenomena that individually may not be extreme. These phenomena occur on a range of time and space scales (Figure 1) in any given coastal location, and thus the contribution of each phenomenon to extreme sea levels varies. Oceanic and atmospheric variability on timescales of weeks to decades also influences local sea levels. For example, sea level variability is strong over northern Australia where monthly sea-level anomalies are highly correlated with the Southern Oscillation Index (SOI), a measure of El Niño-Southern Oscillation (ENSO; Figure 2a, Holbrook et al. 2011). Positive (negative) perturbations in sea levels during La Niña (El Niño) propagate from the equatorial western Pacific Ocean through the Indonesian Archipelago to northwestern Australia and then anticlockwise around Australia, decreasing in magnitude with distance from Darwin (White et al. 2014).

Astronomical tides vary on multiple timescales, including diurnal and semi-diurnal, fortnightly with spring and neap tides, and on seasonal to interannual timescales. Around the coast of Australia, overall highest astronomical tides (HAT, considered over an 18.6 year lunar tidal epoch following common practice) vary between around $0.5 \mathrm{~m}$ (e.g. in areas of southwest Australia) to well over $7 \mathrm{~m}$ along the northwest coast (Figure $2 \mathrm{~b}$ ); daily mean tidal range patterns are similar to that of HAT. Furthermore tide types range from strongly diurnal, to 
mixed, through to semi-diurnal along the coastline (Figure $2 \mathrm{c}$ ); the timing and relative range of (semi-annual) maximum spring tides also vary (Figure $2 \mathrm{~d}$ ).

82 Storm surges, in comparison, are gravity waves arising from the inverse barometer effect and 83 wind stress. The former elevates sea levels approximately $1 \mathrm{~cm}$ for every $1 \mathrm{hPa}$ fall in atmospheric pressure relative to surrounding conditions, and wind stress induces currents over shallow water. Wind stress directed onshore (i.e. "wind setup") leads to an increase in sea levels, particularly within semi-enclosed embayments or under severe wind forcing such as produced by tropical cyclones (TCS). In mid-latitudes, wind-induced coast-parallel currents, which persist for a day or more, undergo Coriolis deflection. In the southern hemisphere this increases (decreases) coastal sea levels if the currents follow the coast in an anticlockwise (clockwise) direction and is referred to as "current setup" ("setdown"). Using a hydrodynamic model forced by tides and atmospheric conditions, Haigh et al. $(2014 a, b)$ assessed return periods of storm surges and tides (i.e. storm tides) around the Australian coast. The highest storm tides (100-year return period levels $>4 \mathrm{~m}$ ) occur on the northwest coast, while along the northeast and the mid-southern coastline storm tides are between $2-4 \mathrm{~m}$, and along the southeast and southwest coasts are typically $<2 \mathrm{~m}$.

Meteo-tsunamis are another source of extreme sea levels that arise from abrupt changes in pressure or wind during squalls, thunderstorms or frontal passages. Meteo-tsunamis are shallow-water waves, characterized by wave length much greater than water depth, and a wave period similar to seismic tsunamis (Pattiaratchi and Wijeratne 2014).

Coastally-trapped waves (CTWs) also drive sea level variability along Australia's extratropical coastline on timescales between one day and several months. CTW amplitudes are closely correlated with the continental shelf width and vary from around $0.7 \mathrm{~m}$ along the south coast 
to $0.05-0.10 \mathrm{~m}$ along the east coast. In some cases, sea surface height anomalies are a direct response of the ocean surface to the changing wind field from moving weather systems; in other cases, CTWs propagate freely in the absence of wind forcing (Eliot and Pattiaratchi, 2010; Woodham et al. 2013).

107 The dissipation of wind and swell waves in the nearshore swash zone also contribute to coastal sea levels. Wave setup is an increase in mean water level due to the cross-shore gradient in momentum flux directed shoreward of the region where wave breaking occurs, whereas runup refers to the uprush of water as an individual waves break. Because wave setup and runup are caused by wave breaking, sheltered coastal areas such as harbours and lagoons-the typical location of tide gauges-generally do not experience these effects (Hoeke et al. 2013).

114 The magnitude of wind-waves is a function of the driving wind speed and the fetch-length 115 over which the wind is blowing. Once generated, wind-waves can travel long distances across 116 the deep ocean with little loss of energy until shoaling near the coast. In Australia, the largest 117 waves occur along the southern margin-from North-West Cape, Western Australia (WA), 118 around the southern coast to the southern tip of Tasmania-where waves, generated by the 119 extra-tropical cyclones (ETCs) of the Southern Ocean, propagate towards and eventually 120 break on the coast. Satellite altimeter-derived estimates of the $20(100)$ year return periods of significant wave height (Hs) along Australia's southern margin have been estimated to be approximately 13 m (16 m) (Izaguirre et al. 2011; Vinoth and Young 2011). In northern 123 Australia, TCs are the predominant driver of extreme waves with 100-year Hs estimated to be $12410 \mathrm{~m}$ (Vinoth and Young 2011). 
Other coastal attributes, such as continental shelf width, bathymetric depth, coastline orientation in relation to prevailing weather conditions, headlands, estuaries and shoreline slopes, also influence extreme sea levels. The wider shelf regions along the tropical and much of the southern Australian coastline (Figure 3) are conducive to larger storm surges and tidal ranges whereas the narrower shelves along the southeast, southwest and parts of the southern coastline are exposed to wave-driven coastal extremes. Coral reefs, found along the northeast (Great Barrier Reef; GBR), north and northwest (e.g. the Ningaloo Reef) of Australia, also provide coastal protection through wave dissipation offshore (e.g. Gallop et al. 2014).

\subsection{Weather and climate drivers}

134 A range of weather conditions cause extreme sea levels around the Australian coastline 135 (Figure 3). TC-induced storm surges affect mainly the northern coastline of Australia from 136 Queensland to the northwest coast of Western Australia although TCs can track and hence 137 influence the east and west coastlines further south (Haigh et al. 2014b). Within the Gulf of 138 Carpentaria an annual cycle of sea level, with a range of approximately $0.8 \mathrm{~m}$, driven mainly 139 by the seasonal reversal of the prevailing winds, produces the largest seasonal variation in 140 sea levels in the world (Forbes and Church 1983; Tregoning et al. 2008; White et al. 2014). 141 Westerly wind bursts associated with the Madden-Julian Oscillation (MJO) during the 142 monsoon contribute to intra-seasonal sea level variations along the Gulf of Carpentaria and 143 Indian Ocean coastlines (Oliver and Thompson 2011). Strong sustained south-easterly trade 144 winds during the dry season can elevate sea levels in the Torres Strait Islands (Green et al. 145 2010).

146 Easterly or northeasterly travelling ETCs or TCs cause elevated sea levels along the southwest 147 WA coastline (Haigh et al. 2010; Eliot et al. 2012), which may be further enhanced by a sea 
level annual cycle of $0.2-0.3 \mathrm{~m}$ due to variations in the strength of the southward flowing Leeuwin current. During May to June, weak southerly winds allow for a stronger flowing southward current and higher coastal sea levels due to Coriolis deflection, whereas during October to November, the opposing southerly winds are strongest and this weakens the Leeuwin current (Pattiaratchi and Eliot 2008).

Eastward travelling ETCs and fronts, most frequent during the winter months, are the main cause of elevated sea levels along the southern coastline and Tasmania (McInnes and Hubbert 2003; Mclnnes et al. 2012b; Colberg and Mclnnes 2012). Along Australia's east coast, from New South Wales (NSW) to southeast Queensland (QLD), a major cause of elevated sea levels is from East Coast Lows (Mclnnes and Hubbert 2001; Walsh et al. this issue).

Modes of climate variability also influence weather systems that cause extreme sea levels (Westra et al. this issue). In addition to its influence on sea levels ENSO affects TC frequency, with more (fewer) TCs likely during La Niña (El Niño) events (Kuleshov et al. 2008). The MJO also affects TC occurrence (Hall et al. 2001). The Southern Annular Mode (SAM), which in its positive phase amounts to a strengthening and poleward shift of storm tracks, affects the latitudinal position of the Subtropical Ridge (STR), which separates easterly trade winds to the north and the westerlies to the south (Kent et al. 2013) and, hence, extreme sea levels on the southern coastline. The Indian Ocean Dipole (IOD) also affects regional sea levels to the northwest of Australia (Feng and Meyers 2003) with the Dipole Mode Index weakly negatively correlated with coastal sea levels along the WA coast (Charitha Pattiaratchi, pers. comm. September 2015).

\subsection{Terrestrial factors}


170 Extreme sea level impacts at the coast, such as inundation and erosion, are influenced by

terrestrial factors including vertical land movement, geomorphology, fluvial contributions and anthropogenic modifications to the coastal landscape. In addition to flooding from sea level extremes, cliff instability and beach erosion may also occur from sea level rise (SLR) and storm and wave-climate changes (Department of Climate Change 2009).

As well as long-term vertical land movement from Glacial Isostatic Adjustment (GIA), local vertical movements can occur due to natural processes such as sustained or abrupt tectonic disturbances, and anthropogenic causes such as sediment consolidation, reduced sediment delivery to the coast, and extraction of subsurface resources such as gas and groundwater (Wong et al. 2014). Among Australian tide gauge locations with co-located Global Positioning System (GPS) technology, White et al. (2014) estimated subsidence rates at Hillarys, Perth, Darwin and Adelaide of $-3.1( \pm 0.7),-2.1( \pm 0.7),-1.6( \pm 1.4)$ and $-0.4( \pm 0.3) \mathrm{mm} \mathrm{yr}^{-1}$ respectively.

In estuarine regions, floods can be caused not only by elevated ocean levels, but also by fluvial contributions arising from heavy rainfall on the catchment. The nature of floods in these regions is complex (Johnson et al. this issue), with flood magnitude dependant on intensity and duration of the extreme rainfall event (Leonard et al. 2008), antecedent catchment conditions (Johnson et al. this issue) and whether the hydrograph peak coincides with the peak in extreme sea levels (Zheng et al. 2015). Because extreme rainfall and storm surges are often produced by similar weather patterns, there is a significant probability that both processes will occur simultaneously (Zheng et al. 2013), with the probability depending on the location along the coastline, the duration and the absolute magnitude of the rainfall and storm surge events (Westra et al. 2015). This means that extreme water levels in estuarine 
areas can occur even when all of the driving processes are individually non-extreme (Leonard et al. 2014).

\section{3. Historical changes and their causes}

\subsection{Historical changes to extreme sea levels}

Trends in mean sea level from Australian tide gauges and satellite altimeters are generally in

close agreement, although tide gauges are known to be affected by vertical land motions.

Variations in mean sea level are strongly related to ENSO-particularly on the northern and western coastlines-as well as the GIA and atmospheric pressure. Correcting for these factors yields Australian trends since 1993 of between $2.1 \pm 0.2 \mathrm{~mm} \mathrm{yr}^{-1}$ and $3.1 \pm 0.6 \mathrm{~mm} \mathrm{yr}^{-1}$ from tide gauges and altimeters respectively (White et al. 2014), which are similar to respective global mean trends over the past 45 years. Generally changes in extreme sea levels are consistent with mean SLR in global tide gauge data (Menéndez and Woodworth 2010). However, at Australia's longest tide gauge records (see Figure 3), extreme sea levels were found to be increasing more rapidly than median sea levels (Church et al. 2006).

The analysis of trends in waves is challenging because of the limited number of long-term wave buoy observations, the earliest of which commenced in the mid-1970s along Australia's east coast (Figure 3). Satellite observations provide an alternative record, and although of limited length (e.g. Young et al. 2011), have been found to be strongly positively correlated with the positive trend in SAM (Westra et al. this issue) particularly from March to August (Hemer et al. 2010).

Wave models forced by winds from atmospheric reanalyses provide an alternative means to study longer-term trends in waves. The latest generation of models represent waves along 
the Australian coast with high skill, although some regional biases exist due to known

limitations of the wave models - for example, parameterisation of the GBR results in positive biases along much of the QLD coast, and known issues with Southern Ocean wind forcing and swell dissipation terms lead to biases along the southern Australian margin, with positive biases in wave height in this region (Hemer et al. 2016). Additionally problems of temporal homogeneity in reanalysis products (Wang et al. 2006) lowers the confidence in the trends.

For extreme waves, Young et al. (2011) found mostly significant positive trends of between $0.5 \%$ and $1.0 \%$ per year in mid-latitude oceans but less clear trends over tropical oceans in 99th-percentile satellite-measured wave heights from 1985 to 2008. Young et al. (2011) suggested that positive trends were evident in the 100-year return period wave heights, but their approach did not resolve the significance. Hemer (2010) also found strong positive trends in the frequency of wave events exceeding the 98th-percentile in reanalysis wave data over 1985 to 2002, but not in data from a wave buoy situated on Tasmania's west coast over the same period. Over the southern Indian Ocean, Bosserelle et al. (2012) found a significant positive trend in annual mean wave height in a reanalysis-forced wave hindcast, also attributed to the positive trend in the SAM, but no significant trends in the 90th percentile wave height or extreme wave frequency (Hs>7 m) impacting Western Australia. Izaguirre et al. (2011) looked at the relationship between interannual variability of altimeter-derived extreme wave heights and several climate drivers, finding only a statistically significant relationship with the SAM index along the western and southern margins of Australia. Shand et al. (2011) reviewed the NSW buoy record-one of the world's longest running wave buoy networks - for trends, and found a positive trend in the number of storms per year over the 
last 22 years. These trends were attributed to a shift in phase in the Interdecadal Pacific Oscillation (IPO) from more El Niño-like to more La Niña-like conditions (Goodwin 2005).

\subsection{Causes of change in coastal extremes and physical impacts}

Although an increase in extreme sea levels due to mean SLR has been demonstrated (Menendez and Woodworth 2010), attribution of increased coastal impacts (i.e. erosion and 243 inundation) to rising sea levels has not been possible due to lack of long-term observations and the confounding effect of other anthropogenic influences such as coastal development, changes in catchment land-use and freshwater input to the coastal zone (Wong et al. 2014).

Several recent Australian studies have focused on the relationship between shoreline change and natural modes of variability. For example, ENSO has been shown to influence storms and hence wave climate and coastline orientation within embayments in eastern Australia (Ranasinghe et al. 2004; Harley et al. 2011). O'Grady et al. (2015) found that ocean currents and waves in eastern Bass Strait are generally correlated with the position of the STR location (which in turn is influenced by ENSO and SAM), resulting in anomalous meridional wind- and wave-driven transport.

\section{Future projections}

\subsection{Projections of regional SLR and extremes}

Mean SLR will continue to be the major driver of increasing extreme sea levels in the future, with the most recent sea level projections from the Intergovernmental Panel on Climate Change (IPCC) assessment incorporating contributions from oceans, glaciers, ice sheets, land water and large-scale vertical land motion from GIA (Church et al. 2013). For 2090, global 
mean SLR projections with 5-95\% range are 0.47 [0.32 to 0.62] $\mathrm{m}$ under a mid-range emissions scenario (RCP 4.5), and 0.62 [0.45 to 0.81] m under a "business-as-usual" emissions scenario (RCP 8.5).

Based on the same approach, but using a different model for GIA, sea-level projections have been developed for Australia (CSIRO and BoM 2015; Mclnnes et al. 2015). Values are larger than global mean SLR projections, especially along the east coast of Australia where the 95thpercentile values for RCP 8.5 in 2090 are up to $0.06 \mathrm{~m}$ higher due to the strengthening subtropical gyre circulation of the South Pacific Ocean (Zhang et al. 2013). The GIA readjustment lowers the SLR by several $\mathrm{cm}$ along the Australian coastline and up to $0.1 \mathrm{~m}$ in the Gulf of Carpentaria, compared to offshore for RCP 8.5 by 2090.

Regarding the use of SLR projections in impact studies, Hunter (2012) derived a SLR "allowance"; the height that assets need to be raised to maintain currently accepted exceedance probabilities of coastal inundation (see also Hunter et al. 2013; Mclnnes et al. 2015). The allowance depends on the characteristics of extreme sea levels, projected mean SLR and its range. However, it does not presently account for future changes in the characteristics of extreme sea levels (i.e. frequency and intensity) that may result from climate change. Weather and circulation changes are unlikely to cause large changes in the characteristics of extreme sea levels over much of the coastline compared to the changes brought about by SLR alone (Colberg and Mclnnes 2012), however it is possible that the future movement of circulation patterns may lead to larger changes in the characteristics of extremes in localized parts of the coastline (e.g. O'Grady et al. 2015).

\subsection{Projections of wave climate and storm surge}


Projections of future wind-wave climate have been undertaken at the global and regional scale. The NSW coast has received most attention regionally (e.g. Hemer et al. 2013b; Dowdy et al. 2014; Kinsela et al. 2014). Hemer et al. (2013b) found wave direction to be most susceptible to future climate change, mainly due to its sensitivity to the position of the STR. They also noted that synoptic drivers of wave events on the NSW coast are poorly represented in both global and regional General Circulation Models (GCMs). Dowdy et al. (2014) utilized statistical downscaling to provide projections of large waves on the east Australian coast, reporting fewer large waves due to decreasing storminess.

Several global wave climate studies provide wave projections for the Australian coast using Coupled Model Intercomparison Project Phase 3 (CMIP3; e.g. Hemer et al. 2013c; Fan et al. 2014) and CMIP5 (Hemer and Trenham 2015 and references therein) GCMs. Most studies have focused initially on projections of mean wave climate, although Hemer et al. (2013a) indicate that the distribution of projected changes of the 99th-percentile and mean is similar but scaled by a factor of approximately two. Future increases in southern ocean wave height were projected using CMIP3 models and may impact the Tasmanian coast, particularly during winter, while decreases in wave height were projected elsewhere around the Australian coast (Hemer et al. 2013c). Increase in trade wind-generated waves have been projected along the QLD coast, although this was countered by a projected decrease in wave heights during the monsoon months - a result that is strongly dependent on GCM ability to represent the Coral Sea cyclone systems. Wave projections based on CMIP5 experiments are largely consistent with those based upon CMIP3 results.

Only one published study to date examines the impact of future changes in storm behavior on extreme sea levels in Australia (Colberg and Mclnnes 2012). Projected changes in 95th- 
percentile sea surface height in CMIP3-forced GCMs and regional GCMs were mostly small

(within $\pm 0.1 \mathrm{~m}$ ) and resembled the changes in wind patterns simulated by the GCMs to some

degree, although inter-model differences were apparent.

\subsection{Projections of coastal impacts}

Assessments of how projected SLR will affect coastal inundation and erosion in Australia have been undertaken in several studies. Inundation studies such as the national coastal

vulnerability assessment (Department of Climate Change 2009) have used static infill (i.e. bathtub) approaches in which projections of SLR are added to appropriate coastal extreme sea levels (usually the 100-year storm tide level) and inundation extent calculated. High resolution LiDAR-derived elevations and 100-year storm tides combined with various SLR projections were used for Victoria (Mclnnes et al. 2013) and Sydney (Mclnnes et al. 2012a). These methods, while providing useful guidance for areas most vulnerable, do not capture processes such as riverine input, or their projected changes due to climate change (see Johnson et al, this issue), frictional attenuation of flows, and obstacles that may either permit or limit flow and hence influence inundation during extreme events (McInnes et al. 2013).

While a large-scale assessment of erosion risk was undertaken nationally (Department of Climate Change 2009) using simple Bruun Rule assumptions (Bruun 1962), an emerging approach is to assess coastline response at the coastal compartment scale using physicsbased models that account for both ephemeral (storm-based) and chronic (long-term SLRinduced) erosion (Woodroffe et al. 2012).

Using the Probabilistic Coastal Recession (PCR) Model, which accounts for the combined effect of SLR, storm surge and storm waves, Ranasinghe et al. (2012) calculated a $1 \%$ 
exceedance probability recession of $45 \mathrm{~m}$ at Narrabeen Beach, NSW and noted that Bruun Rule-based estimates at the same location (for the same SLR) had a less than $8 \%$ probability of being exceeded implying that Bruun rule-derived recession estimates may promote wide, highly conservative coastal buffer zones. This finding further justifies the increasing concerns about using the Bruun Rule to derive quantitative estimates of SLR-driven coastline recession (e.g. Cooper and Pilkey 2004; Ranasinghe and Stive 2009). Wainwright et al. (2015) used the PCR model in combination with the Shoreface Translation Model (Cowell et al. 1995) and stochastic selection of SLR to simulate long term coastline trends. They demonstrated for Narrabeen beach that the Economically Optimal coastal Setback Lines (EOSL) could be determined from such quantitative assessments and that considerable existing infrastructure is located seaward of the EOSL. By combining various modelling techniques including coastline, coastal profile and 2D hydrodynamic coastal area models, Huxley (2011) showed that coastline recession at Wooli Wooli and Batemens Bay in NSW from both SLR and projected wave changes could be up to $40 \mathrm{~m}$ by 2100 .

At the many inlet-interrupted coasts around Australia (especially NSW and WA), coastline change will likely be affected not only by SLR but also by variations in river flows. Ranasinghe et al. (2013) applied a physics-based scale-aggregated model to the WA coast near Swan River (Fremantle) and Wilson inlet (Denmark) and predicted worst-case recessions of about $180 \mathrm{~m}$ and $150 \mathrm{~m}$ respectively. However, application of the Bruun Rule yielded recessions that were about 50\% lower, highlighting its inaccuracy along inlet-interrupted coastlines. 


\section{Conclusions, knowledge gaps and recommendations}

347 As part of this Special Issue on Australian natural hazards, this review has summarized the 348 most recent scientific advances in both the measurement and understanding of sea level and 349 coastal extremes, and documented the state of our knowledge on projected future changes. 350 In this section, we discuss knowledge gaps and future research priorities.

351 While significant recent advances have been made in understanding trends in sea level 352 around Australia over the $20^{\text {th }}$ and early part of the $21^{\text {st }}$ Century, understanding of changes in 
detection and attribution) as well as a more complete understanding of the relationship between wave climate and littoral transport processes. There also remains a need to better understand how sea level and wave extremes during the instrumental period fit within the broader context of paleo-climate reconstructions (e.g. Goodwin et al. 2004; Nott et al. 2013). Such efforts would help constrain uncertainties around both present day and projected future changes to sea level and coastal extremes.

There has been considerable advancement in the projection of SLR with greater understanding of how the contributing processes affect regional SLR projections. However the relatively low resolution of GCMs means that continental shelves are poorly resolved. An improved understanding of SLR at the regional scale will be facilitated by emerging higherresolution, horizontal eddy-resolving ocean models (typically $10 \mathrm{~km}$ resolution) that are capable of resolving shelf dynamics. An important limitation on assessing the impacts of SLR in support of adaptation activities is the limited knowledge of local vertical land movements and their projected future changes. This would be improved by increasing the number of ongoing geodetic observations such as continuous GPS observations.

The most recent IPCC assessment assigns low confidence to future projections of waves and in particular, storm surges (Church et al. 2013) due to the limited number of studies, limited regional coverage of storm surge studies and large uncertainties in the ability of GCMs to simulate severe weather events. Higher-resolution GCMs, improved regional climate models and downscaling approaches will help resolve the relationship between severe weather events and climate including the sequencing of storm events which in turn will improve simulations of waves and storm surges and resulting coastal impacts. Advancements in computing and hydrodynamic models mean that a greater focus on understanding past and 
391

392

future storm surge changes over larger geographical regions is becoming increasingly possible (e.g. Verlaan et al. 2015), but future efforts also need to consider the combination of storm surge and wave-generated extreme sea levels.

How the Australian coastline will respond to SLR and extreme events, such as storm surges and waves through erosion or deposition, remains a major gap in our knowledge. Coastline response is dependent not only on changes to the climatic drivers, but also on coastal geomorphology. A better understanding is needed of how different climatic drivers operating on different spatio-temporal scales manifest in the coastal zone, yet few long-term observational coastal records, such as the Narrabeen record, are available to build this knowledge. Such understanding needs to incorporate coastal hydrodynamic processes that occur both in a cross-shore (vertically non-uniform) and longshore (mostly vertically uniform) 402 sense. The challenge, however, lies in modelling morphological change due to the combined 403 effect of waves and currents at timescales greater than a few years. Scale-aggregated 404 modelling, in which the main physical processes that govern coastline position are 405 parameterised and collectively represented by fully explicit governing equations, may offer 406 an efficient approach to quantify climate change impacts and their uncertainties on coasts 407 (e.g. Stive and Wang 2003; Ranasinghe et al. 2013). However, significant efforts are needed 408 to develop and test such approaches for modelling coastline change.

409 Finally, within estuaries, the number and value of assets that may be impacted by oceanic 410 extremes is at least an order of magnitude higher than those on the open coast. The 411 interactions and dependencies in space and time of tide, surge, wave setup and riverine 412 flooding make the assessment of extreme water levels and inundation within estuaries one 413 of high complexity (Zheng et al. 2013) and in need of further research. 


\section{Acknowledgements}

416 for funding this research. RR is supported by the AXA Research fund. This paper was a result of 417 collaboration through the 'Trends and Extremes' working group as part of the Australian Water and 418 Energy Exchanges Initiative (OzEWEX). 


\section{References}

Bosserelle C., Pattiaratchi C., Haigh I. (2012) Inter-annual variability and longer-term changes in the wave climate of Western Australia between 1970 and 2009. Ocean Dynamics 62:63-76. DOI: 10.1007/s10236-011-0487-3.

Bruun P. (1962) Sea-level rise as a cause of coastal erosion. J. Waterw. Harbours Coastal Eng. Div. Am. Soc. Civ. Eng 88:117-130.

Church J.A., Hunter J.R., McInnes K.L., White N.J. (2006) Sea-level rise around the Australian coastline and the changing frequency of extreme sea-level events. Australian Meteorological Magazine 55:253-260.

Church J.A., Clark P.U., Cazenave A., Gregory J.M., Jevrejeva S., Levermann A., Merrifield M.A., Milne G.A., Nerem R.S., Nunn P.D., Payne A.J., Pfeffer W.T., Stammer D., Unnikrishnan A.S. (2013) Sea Level Change., in: T. F. Stocker, et al. (Eds.), In: Climate Change 2013: The Physical Science Basis. Contribution of Working Group I to the Fifth Assessment Report of the Intergovernmental Panel on Climate Change, Cambridge University Press, Cambridge, United Kingdom and New York, NY, USA.

Colberg F., McInnes K.L. (2012) The impact of future changes in weather patterns on extreme sea levels over southern Australia. Journal of Geophysical Research: Oceans 117:C08001. DOI: 10.1029/2012jc007919.

Cooper J.A.G., Pilkey O.H. (2004) Sea-level rise and shoreline retreat: time to abandon the Bruun Rule. Global and Planetary Change 43:157-171.

Cowell P., Roy P., Jones R. (1995) Simulation of large-scale coastal change using a morphological behaviour model. Marine Geology 126:45-61.

CSIRO, BoM. (2015) Climate Change in Australia Information for Australia's Natural Resource Management Regions, CSIRO and Bureau of Meteorology. pp. 222 pp.

Department of Climate Change. (2009) Climate Change Risks to Australia's Coast. A First Pass National Assessment. Report published by the Australian Government's Department of Climate Change.

Dowdy A.J., Mills G.A., Timbal B., Wang Y. (2014) Fewer large waves projected for eastern Australia due to decreasing storminess. Nature Clim. Change 4:283-286. DOI: 10.1038/nclimate2142

Eliot M. (2012) Sea level variability influencing coastal flooding in the Swan River region, Western Australia. Continental Shelf Research 33:14-28. DOI: http://dx.doi.org/10.1016/j.csr.2011.08.012.

Eliot M., Pattiaratchi C. (2010) Remote forcing of water levels by tropical cyclones in southwest Australia. Continental Shelf Research 30:1549-1561. DOI:

Fan Y., Lin S.-J., Griffies S.M., Hemer M.A. (2014) Simulated global swell and wind-sea climate and their responses to anthropogenic climate change at the end of the twenty-first century. Journal of Climate 27:3516-3536.

Feng M., Meyers G. (2003) Interannual variability in the tropical Indian Ocean: a two-year time-scale of Indian Ocean Dipole. Deep Sea Research Part II: Topical Studies in Oceanography 50:22632284. DOI: http://dx.doi.org/10.1016/S0967-0645(03)00056-0.

Gallop S.L., Young I.R., Ranasinghe R., Durrant T.H., Haigh I.D. (2014) The large-scale influence of the Great Barrier Reef matrix on wave attenuation. Coral reefs 33:1167-1178.

Goodwin I.D. (2005) A mid-shelf, mean wave direction climatology for southeastern Australia, and its relationship to the El Niño-Southern Oscillation since 1878 AD. International Journal of Climatology 25:1715-1729.

Green D., Alexander L., McInnes K.L., Church J., Nicholls N., N. W. (2010) An assessment of climate change impacts and adaptation for the Torres Strait Islands. Climatic Change 102:405-433 DOI: 10.1007/s10584-009-9756-2 
Haigh I., Eliot M., Pattiaratchi C. (2010) Historic changes in storm surges around southwestern Australia, 15th Physics of Estuaries and Coastal Seas Conference, Columbo.

Haigh I., Wijeratne E.M.S., MacPherson L., Pattiaratchi C., Mason M., Crompton R., George S. (2014a) Estimating present day extreme water level exceedance probabilities around the coastline of Australia: tides, extra-tropical storm surges and mean sea level. Climate Dynamics 42:121138. DOI: 10.1007/s00382-012-1652-1.

Haigh I., MacPherson L., Mason M., Wijeratne E.M.S., Pattiaratchi C., Crompton R., George S. (2014b) Estimating present day extreme water level exceedance probabilities around the coastline of Australia: tropical cyclone-induced storm surges. Climate Dynamics 42:139-147. DOI: 10.1007/s00382-012-1653-0.

Hall J.D., Matthews A.J., Karoly D.J. (2001) The modulation of tropical cyclone activity in the Australian region by the Madden-Julian Oscillation. Monthly Weather Review 129:29702982.

Harley M., Turner I., Short A., Ranasinghe R. (2011) A reevaluation of coastal embayment rotation: The dominance of cross-shore versus alongshore sediment transport processes, CollaroyNarrabeen Beach, southeast Australia. Journal of Geophysical Research: Earth Surface (2003-2012) 116.

Hemer M.A. (2010) Historical trends in Southern Ocean storminess: Long-term variability of extreme wave heights at Cape Sorell, Tasmania. Geophysical Research Letters 37.

Hemer M.A., Trenham C.E. (2015) Evaluation of a CMIP5 derived dynamical global wind wave climate model ensemble. Ocean Modelling submitted.

Hemer M.A., Church J.A., Hunter J.R. (2010) Variability and trends in the directional wave climate of the Southern Hemisphere. International Journal of Climatology 30:475-491.

Hemer M.A., Katzfey J., Trenham C.E. (2013a) Global dynamical projections of surface ocean wave climate for a future high greenhouse gas emission scenario. Ocean Modelling 70:221-245.

Hemer M.A., Mclnnes K.L., Ranasinghe R. (2013b) Projections of climate change-driven variations in the offshore wave climate off south eastern Australia. International Journal of Climatology 33:1615-1632. DOI: 10.1002/joc.3537.

Hemer M.A., Fan Y., Mori N., Semedo A., Wang X.L. (2013c) Projected changes in wave climate from a multi-model ensemble. Nature Clim. Change advance online publication. DOI: http://www.nature.com/nclimate/journal/vaop/ncurrent/abs/nclimate1791.html\#suppleme ntary-information.

Hemer, M.A., Zieger, S., Durrant, T., O’Grady, J., Hoeke, R.K., McInnes, K.L. and Rosebrock, U. 2016: A revised assessment of Australia's national wave energy resource. (in prep)

Hoeke R.K., McInnes K.L., Kruger J.C., McNaught R.J., Hunter J.R., Smithers S.G. (2013) Widespread inundation of Pacific islands triggered by distant-source wind-waves. Global and Planetary Change 108:128-138. DOI: http://dx.doi.org/10.1016/j.gloplacha.2013.06.006.

Hunter J. (2012) A simple technique for estimating an allowance for uncertain sea-level rise. Climatic Change 113:239-252. DOI: 10.1007/s10584-011-0332-1.

Hunter J.R., Church J.A., White N.J., Zhang X. (2013) Towards a global regionally varying allowance for sea-level rise. Ocean Engineering:1-11. DOI: 10.1016/j.oceaneng.2012.12.041i.

Izaguirre C., Méndez F.J., Menéndez M., Losada I.J. (2011) Global extreme wave height variability based on satellite data. Geophysical Research Letters 38:n/a-n/a. DOI: 10.1029/2011gl047302.

Kent D.M., Kirono D.G.C., Timbal B., Chiew F.H.S. (2013) Representation of the Australian subtropical ridge in the CMIP3 models. International Journal of Climatology 33:48-57. DOI: 10.1002/joc.3406.

Kinsela M., Taylor D., Treloar D., Dent J., Garber S., Mortlock T., Goodwin I. (2014) NSW coastal ocean wave model: investigating spatial and temporal variability in coastal wave climates, Ulladulla, NSW: NSW Coastal Conference. 
Kuleshov Y., Qi L., Fawcett R., Jones D. (2008) On tropical cyclone activity in the Southern Hemisphere: trends and the ENSO connection. Geophysical Research Letters 35.

Leonard M., Metcalfe A., Lambert M. (2008) Frequency analysis of rainfall and streamflow extremes accounting for seasonal and climatic partitions. Journal of Hydrology 348:135-147. DOI: http://dx.doi.org/10.1016/j.jhydrol.2007.09.045.

Leonard M., Westra S., Phatak A., Lambert M., van den Hurk B., Mclnnes K., Risbey J., Schuster S., Jakob D., Stafford-Smith M. (2014) A compound event framework for understanding extreme impacts. Wiley Interdisciplinary Reviews: Climate Change 5:113-128.

McInnes K.L., Hubbert G.D. (2001) The impact of eastern Australian cut-off lows on coastal sea levels. Meteorological Applications 8:229-243. DOI: 10.1017/s1350482701002110.

McInnes K.L., Hubbert G.D. (2003) A numerical modelling study of storm surges in Bass Strait. Australian meteorological magazine 52 143-156

McInnes K.L., Lipkin F., O'Grady J.G., Inman M. (2012a) Modelling and Mapping of Coastal Inundation under Future Sea Level., A report for Sydney Coastal Councils Group, . pp. 62 pp.

McInnes K.L., Macadam I., Hubbert G., O'Grady J. (2013) An assessment of current and future vulnerability to coastal inundation due to sea-level extremes in Victoria, southeast Australia. International Journal of Climatology 33:33-47. DOI: 10.1002/joc.3405.

McInnes K.L., Church J.A., Monselesan D., Hunter J.R., O'Grady J.G., Haigh I. D., Zhang X. (2015) Sealevel Rise Projections for Australia: Information_for Impact and Adaptation Planning. Australian Meteorological and Oceanographic Journal submitted.

McInnes K.L., O'Grady J.G., Hemer M.A., Macadam I., Abbs D.J., White C.J., Corney S.P., Grose M.R., Holz G.K., Gaynor S.M., Bindoff N.L. (2012b) Climate Futures for Tasmania: Extreme tide and sea-level events, Antarctic Climate and Ecosystems CRC. pp. 40 pp.

Menéndez M., Woodworth P.L. (2010) Changes in extreme high water levels based on a quasi-global tide-gauge data set. Journal of Geophysical Research: Oceans 115:C10011. DOI: 10.1029/2009jc005997.

Nott J., Green C., Townsend I., Callaghan J. (2013) The World Record Storm Surge and the Most Intense Southern Hemisphere Tropical Cyclone: New Evidence and Modeling. Bulletin of the American Meteorological Society 95:757-765. DOI: 10.1175/bams-d-12-00233.1.

O'Grady J.G., McInnes K.L., Colberg F., Hemer M.A., Babanin A.V. (2015) Longshore wind, waves and currents: climate and climate projections at Ninety Mile Beach, southeastern Australia. International Journal of Climatology:n/a-n/a. DOI: 10.1002/joc.4268.

Oliver E.C.J., Thompson K.R. (2011) Sea level and circulation variability of the Gulf of Carpentaria: Influence of the Madden-Julian Oscillation and the adjacent deep ocean. Journal of Geophysical Research: Oceans 116:C02019. DOI: 10.1029/2010jc006596.

Pattiaratchi C., Wijeratne E. (2014) Observations of meteorological tsunamis along the south-west Australian coast. Natural Hazards 74:281-303.

Pattiaratchi C.B., Eliot M. (2008) Sea level variability in southwest Australia: from hours to decades., Proceedings of the 31st ASCE international conference on coastal engineering, Hamburg.

Ranasinghe R., Stive M.J. (2009) Rising seas and retreating coastlines. Climatic Change 97:465-468.

Ranasinghe R., Callaghan D., Stive M.J. (2012) Estimating coastal recession due to sea level rise: beyond the Bruun rule. Climatic Change 110:561-574.

Ranasinghe R., McLoughlin R., Short A., Symonds G. (2004) The Southern Oscillation Index, wave climate, and beach rotation. Marine Geology 204:273-287.

Ranasinghe R., Duong T.M., Uhlenbrook S., Roelvink D., Stive M. (2013) Climate-change impact assessment for inlet-interrupted coastlines. Nature Clim. Change 3:83-87. DOI: http://www.nature.com/nclimate/journal/v3/n1/abs/nclimate1664.html\#supplementaryinformation.

Seneviratne S., Nicholls N., Easterling D., Goodess C., Kanae S., Kossin J., Luo Y., Marengo J., Mclnnes K., Rahimi M., Reichstein M., Sorteberg A., Vera C., Zhang X. (2012) Changes in climate extremes and their impacts on the natural physical environment. , In: 'Managing the Risks of 
Extreme Events and Disasters to Advance Climate Change Adaptation' A Special Report of Working Groups I and II of the Intergovernmental Panel on Climate Change (IPCC), Cambridge University Press, Cambridge, UK, and New York, NY, USA. pp. 109-230.

Shand T.D., Carley J.T., You Z.J.a., Cox R.J. (2011) Long-term trends in NSW coastal wave climate and derivation of extreme design storms, NSW Coastal Conference Tweed Heads.

Tregoning P., Lambeck K., Ramillien G. (2008) GRACE estimates of sea surface height anomalies in the Gulf of Carpentaria, Australia. Earth and Planetary Science Letters 271:241-244.

Verlaan M., De Kleermaeker S., Buckman L. (2015) GLOSSIS: Global storm surge forecasting and information System, Australasian Coasts and Ports Conference, Auckland, New Zealand.

Wainwright D., Ranasinghe R., Callaghan D., Woodroffe C., Jongejan R., Dougherty A., Rogers K., Cowell P. (2015) Moving from deterministic towards probabilistic coastal hazard and risk assessment: Development of a modelling framework and application to Narrabeen Beach, New South Wales, Australia. Coastal Engineering 96:92-99.

Wang X.L., Swail V.R., Zwiers F.W. (2006) Climatology and changes of extratropical cyclone activity: Comparison of ERA-40 with NCEP-NCAR reanalysis for 1958-2001. Journal of Climate 19:3145-3166.

Westra S., Leonard M., Zheng F. (2015) Joint Probability Modelling in Estuarine Regions Engineers Australia.

White N.J., Haigh I.D., Church J.A., Keon T., Watson C.S., Pritchard T., Watson P.J., Burgette R.J., Eliot M., McInnes K.L., You B., Zhang X., Tregoning P. (2014) Australian Sea Levels - Trends, regional variability and Influencing Factors. Earth-Science Reviews. 136:155-174

Wong P.-P., Losada I.J., Gattuso J.P., Hinkel J., Khattabi A., McInnes K.L., Saito Y., Sallenger A. (2014) Coastal Systems and Low-Lying Areas, Climate Change 2014:Impacts, Adaptation, and Vulnerability. Part A: Global and Sectoral Aspects. Contribution of Working Group II to the Fifth Assessment Report of the Intergovernmental Panel on Climate Change Cambridge University Press, Cambridge, United Kingdom and New York, NY, USA, (in press).

Woodham R., Brassington G.B., Robertson R., Alves O. (2013) Propagation characteristics of coastally trapped waves on the Australian Continental Shelf. Journal of Geophysical Research: Oceans 118:4461-4473. DOI: 10.1002/jgrc.20317.

Woodroffe C., Cowell P., Callaghan D., Ranasinghe R., J, ongejan R, Wainwright D., Barry S., Rogers K., Dougherty A. (2012) Approaches to risk assessment on Australian coasts:-_a model framework for assessing risk and adaptation to climate change on Australian coasts, National Climate Change Adaptation Research Facility, Gold Coast, 205 pp.

Young I.R., Zieger S., Babanin A.V. (2011) Global Trends in Wind Speed and Wave Height. Science 332:451-455. DOI: 10.1126/science.1197219.

Zhang X., Church J.A., Platten S.M., Monselesan D. (2013) Projection of subtropical gyre circulation and associated sea level changes in the Pacific based on CMIP3 climate models. Climate Dynamics. DOI: 10.1007/s00382-013-1902-x.

Zheng F., Westra S., Sisson S.A. (2013) Quantifying the dependence between extreme rainfall and storm surge in the coastal zone. Journal of Hydrology 505:172-187.

Zheng F., Leonard M., Westra S. (2015) Application of the design variable method to estimate coastal flood risk. Journal of Flood Risk Management (in press). 
1 Figures

2
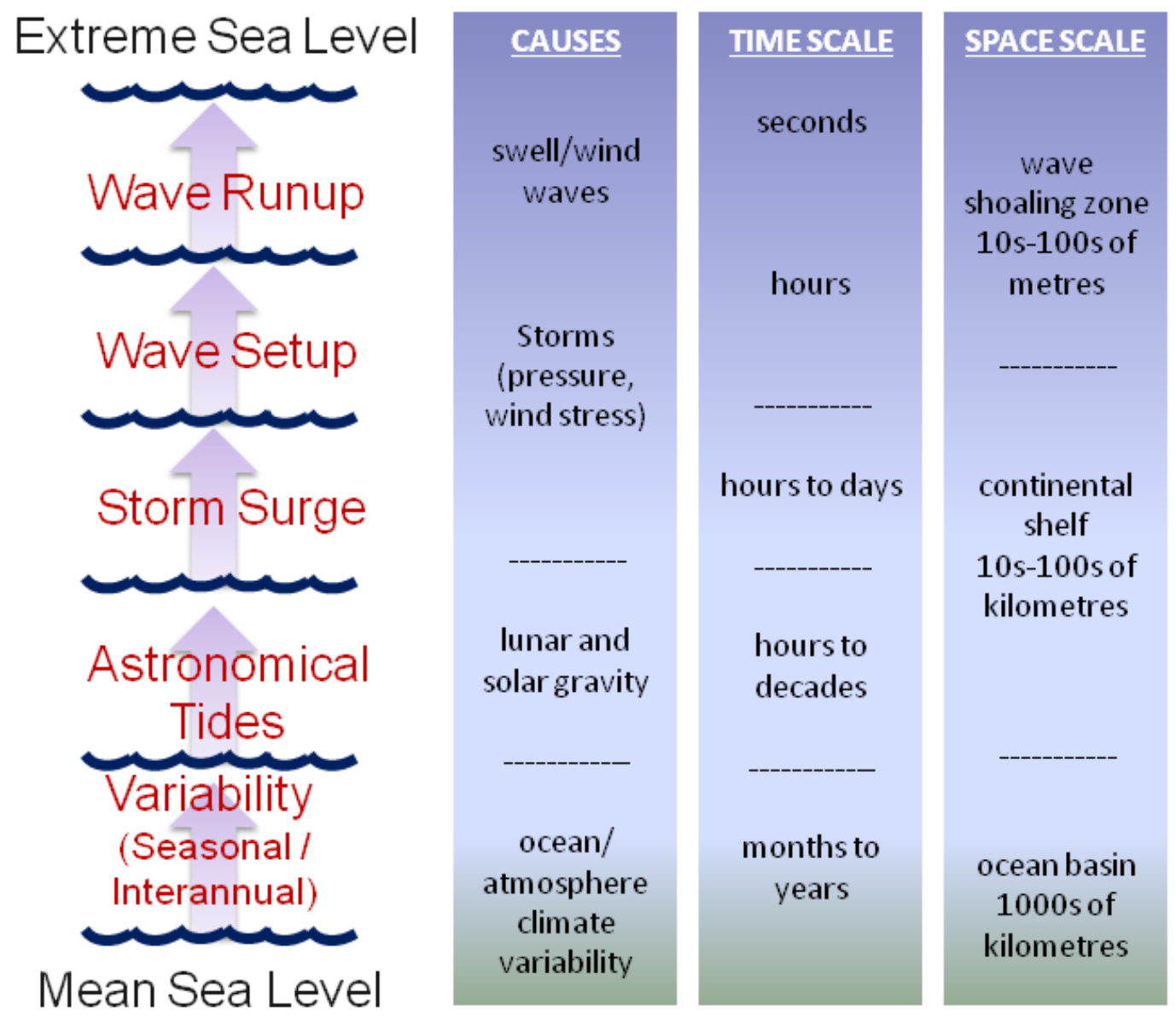

3

Figure 1: Oceanic phenomena that contribute to the total water levels at the coast during an extreme sea level event, their causes and the time and space scales over which they operate.

8 

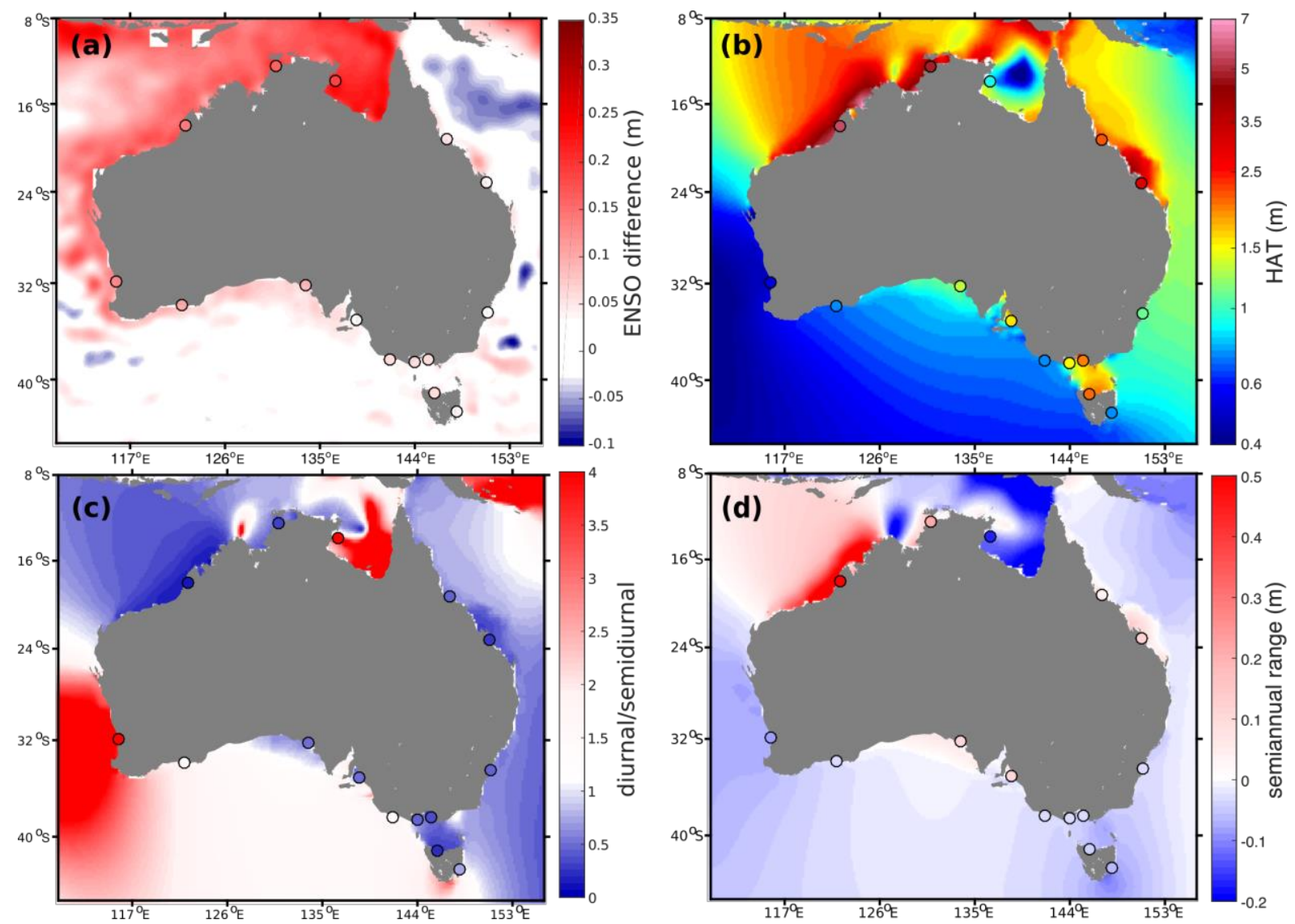

Figure 2: Tide gauge and satellite altimetry derived ENSO-dependent sea-level differences and astronomic tidal characteristics around Australia: (a) differences between La Ninã and El Ninõ sea levels conditions, defined as median monthly sea-level during periods when SOI>1 minus periods when SOI<-1. (b) Highest astronomical tide (HAT) relative to MSL on a logarithmic scale. (c) Tide type, defined as the ratio of the amplitude of the principle diurnal constituents $(K 1, O 1)$ to the semidiurnal constituents $(M 2, S 2)$; when this ratio is $>3$ tides are considered fully diurnal in nature, $<3$ to $>0.25$ they are mixed and $<0.25$ they are diurnal. (d) Range in semiannual tidal amplitude (indicated by $2 \mathrm{~K} 2-2 \mathrm{O} 1$ constituents); positive (negative) values indicate peak astronomical spring tides occur near the equinoxes (solstices). Black circles indicate tide gauges in the Australian Baseline Sea Level Monitoring Project network; circle interior colours indicate values derived from hourly sea-level observations; gridded data values are independently calculated from the following sources:

(a) AVISO DT MSLA "all sat merged" (www.aviso.altimetry.fr); (b-d) TPXO7-Atlas (volkov.oce.orst.edu/tides). 


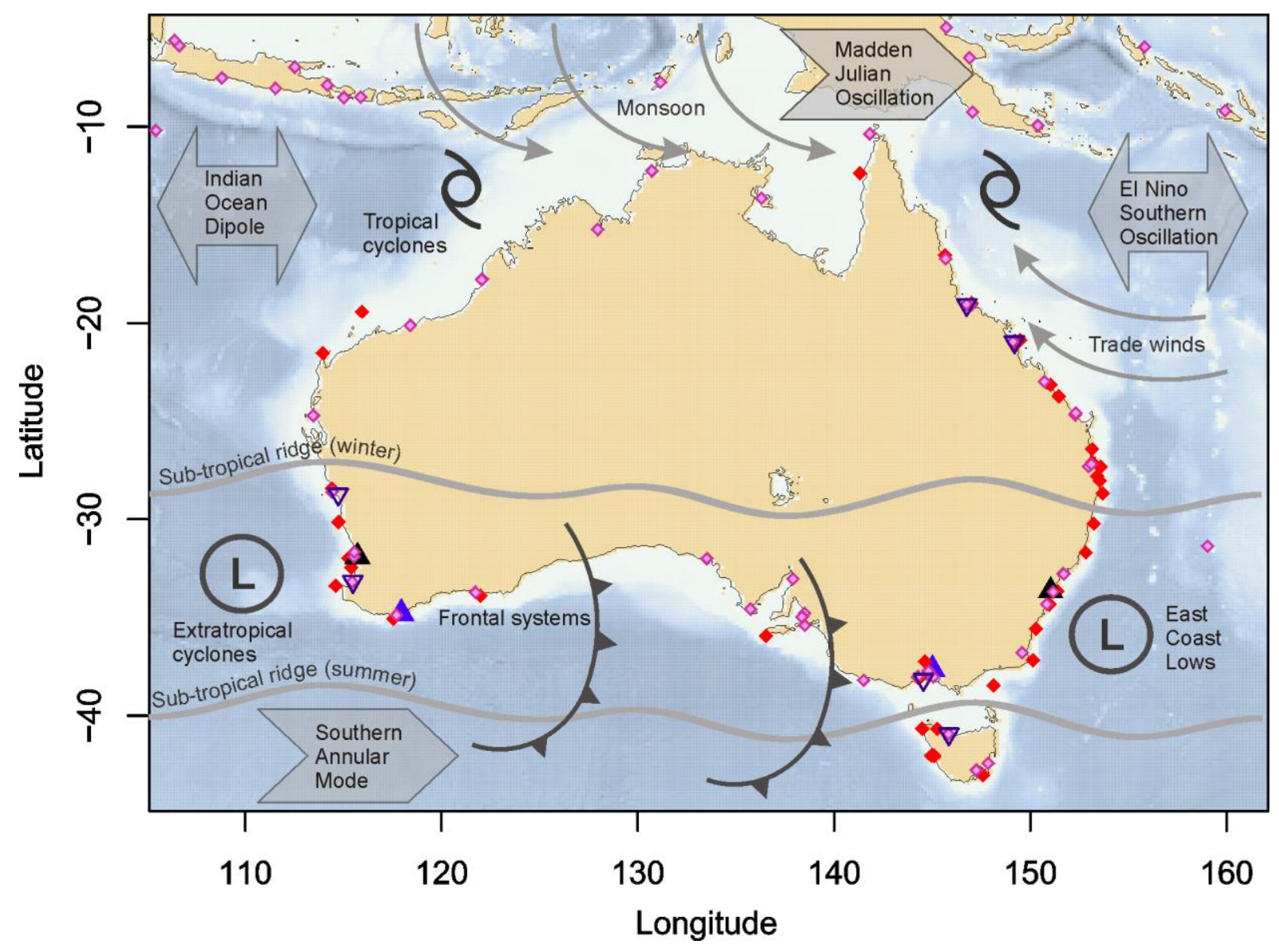

Figure 3: Australian coastline showing tide gauge locations from the GESLA (Hunter et al 2013) dataset (pink-filled diamonds), locations of Australia's two longest hourly digital tide gauge data (large black triangles) at Fremantle in the west commencing in 1897 and Fort Denison in the east commencing in 1914, locations where digitization could extend the hourly records to the late $19^{\text {th }}$ century (large solid blue triangles) and locations where digitization could extend the hourly record back at least to 1950 (open blue triangles). Red diamonds indicate locations of wave buoy data. The weather and climate drivers discussed in relation to extreme coastal sea levels are also illustrated. Light-to-dark shading over the ocean indicates shallow-to-deep bathymetry respectively. 